\title{
TAX TREATMENT OF STOCKHOLDER-TRANSFEREES' PAYMENTS IN SATISFACTION OF DISSOLVED CORPORATIONS' UNPAID DEBTS*:
}

WHEN a former stockholder personally satisfies the debts of a dissolved corporation, the tax consequences of his payment are not clear. Under general corporation law doctrines, stockholder-transferees of a dissolved corporation's assets remain personally liable, up to the amount of their liquidating dividend, for the dissolved corporation's unpaid obligations. 'While Section 115(c) of the Internal Revenue Code treats liquidating dividends as a capital gain or loss to the stockholder recipient, ${ }^{2}$ no Code provision prescribes how the

*Commissioner v. Bauer, 193 F.2d 734 (2d Cir. 1952), cert. granted sub nom, Arrowsmith v. Commissioner, 20 U.S.L. WEEK 3325 (U.S. June 10, 1952); Commissioner v. Switlik, 184 F.2d 299 (3d Cir. 1950).

1. "Where the assets of a dissolved corporation have been distributed among the stocl:holders, a creditor of the dissolved corporation may follow such assets as in the nature of a trust fund into the hands of stockholders.... Where the trust property has been used by the stockholder for his own purpose, or disposed of by him, he may be held personally liable for the full value thereof." Koch v. United States, 138 F.2d 850, 852 (10th Cir. 1943). The basis for this stockholder liability is the doctrine that stockholders who rceeive assets from an insolvent corporation or one which is rendered insolvent by the distribution hold the assets in trust for creditors. 15A Fletcher, Cyclopedia oe Private Corrorations $\$ 7417$ (Rev. ed. 1938). A number of states provide for similar liability by statute. 13 id. $\S 6233$ (Rev. ed 1943). The liability of stockholder-transferees is joint and several. Each transferce is therefore liable to creditors to the full value of the assets received by him. Phillips v. Cummissioner, 283 U.S. 589 (1931). However, he has the right of exacting pro rata contribution from other transferees. Phillips-Jones Corp. v. Parmlcy, 302 U.S. 233 (1937). Enforcing this obligation, the Code provides for the collection through normal tax channels of an insolvent transferor's tax liability from a transferee of his assets. INT. REv. CODE $\$ 311$. The regulations define "transferee" to include the shareholder of a dissolved corporation. U.S. Treas. Reg. 111, \$ 29.311-1(b) (1943).

2. "Amounts distributed in complete liquidation of a corporation shall be treated as in full payment in exchange for the stock, and amounts distributed in partial liquidation of a corporation shall be treated as in part or full payment in exchange of stock." Inr. Rev. CONE $\S 115(\mathrm{c})$. Without this provision, the proceeds of a liquidating dividend, above the cost of the stock, would be taxed in full as an ordinary dividend rather than as a "sale or exchange of a capital asset," qualifying it for capital gains treatment under section 117. Commissioner v. Sansome, 60 F.2d 931 (2d Cir. 1932).

The basis for computing the gain or loss ordinarily is the cost of the stock. Inr. REv. CODE $\S 113$. When the taxpayer receives his liquidating dividend in installments, he must report each installment as a gain as soon as his basis has been recovered. T. T. Word, 41 B.T.A. 965, 981 (1940); O.D. 343, 1 Cuss. BurL. 80 (1919). Losses are not ordinarily realized until the last installment is received. Dresser v. United States, 55 F.2d 499 (Ct. C1. 1932). But if the amount to be received is substantially ascertainable, the loss may be treated as sustained in an earlier year. Commissioner v. Winthrop, 98 F.2d 74 (2d Cir. 1938). See G.C.M. 21966, 1940-1 Cuas. BuLL. 130, reconciling the Dresser and W'inthros cases.

The tax treatment of liquidating dividends has undergone considerable evolution and revision, particularly with regard to dividends in partial liquidation. See Darrell, Corporafe 
stockholder may treat payments in discharge of transferee liability for corporate debts.

At one time the Board of Tax Appeals held such stockholder-transferee payments to be reductions of the liquidating dividend originally received. ${ }^{3}$ The taxpayer accordingly could reopen his tax return which had reported receipt of the liquidating dividend, adjust downward the original capital transaction to reflect the loss from subsequent repayment, and collect a refund. ${ }^{4} \mathrm{~A}$ Stpreme Court dictum in 1932, however, signaled a reversal of this practice. Enunciating the "claim of right" doctrine, the Court held income received "under a claim of right and without restriction as to its disposition," though subject to later repayment, fully taxable in the year of receipt..$^{5}$ In the event of repayment, the Court added, the deduction was to be taken in that later year rather than in the year of original receipt. ${ }^{6}$ The Commissioner and courts, as a result, considered the earlier decisions overruled $:^{7}$ payments in satisfaction of stockholder-transferee liability no longer reduce the liquidating dividend; 8

Liquidations And The Federal Income Tax, 89 U. of PA. L. Rev. 907 (1941); 1 Mertens, LAW OF FEDERAL Income TAXATION $\$ 9.77$ et seq. (1942). At the present time there is no difference in treatment to the recipient of amounts in complete or partial liquidation. Isr. REv. CoDE $\S 115$ (c). U.S. Treas. Reg. 111, \& 29.115-5 (1943).

3. E.g., E. M.F. Leflang, 6 B.T.A. 4 (1927); E.F. Cremin, 5 B.T.A. 1164 (1927); O. B. Barker, 3 B.T.A. 1180 (1926). Cf. Benjamin Paschal O'Neal, 18 B.T.A. 1036 (1930) (taxpayer not entitled to deduction in year of transferee liability payment; however permitted loss deduction for expense of contesting claim). Where liquidating dividends had been received in installments, the transferee payment was first applied against the last dividend received. J. C. Tomlinson, 7 B.T.A. 961 (1927).

4. See cases cited note 3 supra.

5. In North American Oil v. Burnet, 286 U.S. 417 (1932), taxpayer received money in 1917 as a result of winning a district court decision in a dispute with the Government. The Government took an immediate appeal, but settled with the taxpayer in 1922. The taxpayer contended that the money did not constitute income until 1922. In holding that income was realized in 1917, Justice Brandeis wrote for the Court: "If a taxpayer receives earnings under a claim of right and without restriction as to its disposition, he has received income which he, is required to return, even though it may still be claimed that he is not entitled to retain the money, and even though he may still be adjudged liable to restorc its equivalent." Id. at 424.

6. "If in 1922 the Government had prevailed, and the company had been obliged to refund the profits received in 1917, it would have been entitled to a deduction from the profits of 1922, not from those of any earlier year." Ibid.

7. G.C.M. 16730, XV-1 CuM. Bult. 179 (1936); I.T. 2981, XV-1 CuM. BuLl. 274 (1936) ; Schramm v. United States, 36 F. Supp. 1021 (Ct. Cl. 1941). In John T. Furlong, 45 B.T.A. 362 (1941), the board expressiy declared its earlier decisions overruled by the North Anterican Oil case. The board held taxpayer, former member of a dissolved syndicate, entitled to a loss deduction in the year of transferee-payment, despite the Commissioner's inconsistent position that a loss should be deducted from the earlicr gain upon liquidation.

8. Roberta Pittman, 14 T.C. 449 (1950). In the Switlik and Bauer cases discusscd infra, this point was not challenged. But compare Commissioner v. Hartfield, 194 F.2d 662 (2d Cir. 1952) (recipient of excessive salary from insolvent corporation, though held liable for corporation's tax debt, not allowed to reopen return in which salary was reported as ordinary income), with Commissioner v. Smith, 194 F.2d 536 (6th Cir. 1952) (reaching opposite result on almost identical facts). 
instead, they may be deducted only in the year when made. ${ }^{0}$ But whether the deduction is reportable as an ordinary or a capital loss is unresolved; the Second and Third Circuits recently rendered conflicting decisions.

In Commissioner $\%$. Switlik, ${ }^{10}$ stockholder-transferees in 1944 satisfied a tax deficiency assessed against a corporation dissolved in 1941.11 The Third Circuit could not fit the payments into the statutory formula of "losses from the sale or exchange of capital assets." and thus granted the stoclholdertransferees an ordinary loss deduction for 1944. ${ }^{12}$ In Commissioner 2 . Baucr, ${ }^{13}$ stockholder-transferees in 1944 paid a final judgment rendered against a corporation which had liquidated in $1940 .^{1 *}$ Following Switlik, and drawing no distinction between tax and other corporate liabilities, the Tax Court upheld ordinary loss deductions for $1944 .{ }^{10}$ On appeal, however, the Second Circuit expressly disagreed with Switlik and reversed. ${ }^{10}$ The court "tied together" the liquidating dividend and the stockholders' repayment, concluded that the losses in 1944 "show up as arising out of a 'sale or exchange," and held the transferees entitled only to a capital loss deduction. ${ }^{\mathbf{1 7}}$

9. Individual stockholder-transferees receive deductions because their payments represent losses "incurred in transaction entered into for profit" INT. REv. Cone $\$ 23(\mathrm{e})(2)$. The Commissioner accepts this interpretation of the individual loss provision. See, c.g., Stanley Switlik, 13 T.C. 121 (1949), aff'd, 184 F.2d 299 (3d Cir. 1950). Corporations are entitled to deductions for all "losses sustained during the taxable year and not compensated for by insurance or otherwise." INT. REv. CODE $\$ 23(f)$.

10. 184 F.2d 299 (3d Cir. 1950), affirming 13 T.C. 121 (1949), 64 Hasv. L. Kev. S5S (1951). The holding was followed in: Frederick R. Bauer, 15 T.C. 876 (1950), resid, 193 F.2d 734 (2d Cir. 1952) ; Clifton v. Allen, 101 F.Supp. 997 (M.D. G. 1952) ; Frederic MI. Paist, 10 T.C.MI. 967 (1951). Eastland v. United States, 103 F. Supp. 182 (W.D. Tex. 1951) arrived at the same result without citing the Suillik decision. These cases, however, vere decided before the Second Circuit in the Bancr case, discussed infra, reached the opposite result. See note 17 infra.

11. The five transferees had, in 1941, received liquidating dividends from a corporation in which they owned all of the stock In 1942, the Commissioner determined deficiencies in the corporation's tax returns for 1940 and 1941. A compromise agreement was reached in 1944 and the transferees agreed to pay the liability, which for the principal stodsholder amounted to $\$ 22,4 \$ 7.62$. Commissioner v. Switlik, 184 F.2d 299, 300-1 (3d Cir. 1950).

12. Id. at 302 .

13. 193 F.2d 734 (2d Cir. 1952), reversing 15 T.C. 876 (1950). See note 17 infra. Bauer and Switlik are noted in 3S A.B.A.J. 245 (1952).

14. The two taxpayers owned a corporation which completed a series of distributions in complete liquidation in 1940. In 1939, an action had been brought against the corporation and its two stockholders for an accounting in connection with the operation of a joint trading account. The suit was not finally settled until 1944 when a judgment of $\$ 95,926.52$ became final against the corporation and Bauer. Each of the two stockholders paid $\$ 47,963.25$ [sic] in satisfaction of this claim. Frederick R. Bauer, 15 T.C. $876,877-8$ (1950).

15. Id. at $\$ 79$.

16. Commissioner v. Bauer, 193 F.2d 734, 735 (2d Cir. 1952).

17. Ibid. In addition to his argument that stochholder-transferee liability should be given ordinary loss treatment, Bauer contended that, since the personal judgment against him existed apart from transferee-liability, his payment was fully deductible. Erief iur Respondents, p. 24, Commissioner v. Eauer, 193 F.2d 734 (2d Cir. 1952). The curt agrecd 
An individual taxpayer benefits from either an ordinary or a capital loss deduction according to how advantageously he can offset it against taxable income. Ordinary losses, deductible from all taxable income, can of course be deducted only in the year when incurred. ${ }^{18}$ Thus, if the taxpayer in that year has little taxable income, an ordinary loss deduction is not very useful to him. Capital losses, on the other hand, are deductible in the year of loss only from capital gains and ordinary income up to $\$ 1000.10$ Any "unused" capital loss, however, can be carried forward for five successive years, though still deductible only from capital gains and $\$ 1000$ of ordinary income in eacli of the later years. ${ }^{20}$ But in general, taxpayers prefer ordinary loss deductions; offsets against ordinary income taxed at regular progressive rates are more desirable than deductions from capital gains more lightly taxed. ${ }^{\text {"1 }}$ In both Switlik and Bauer, for example, taxpayers contended for ordinary loss treatment which the Commissioner had refused.

Neither Switlik nor Bauer sets up satisfactory tax treatment of stockholdertransferee payments. If the corporation had met its obligations prior to dissolution or had retained a reserve to meet contingent liabilities, the liquidating dividend to stockholders would have been correspondingly reduced.a2 For the stockholder, that reduction would only have diminished a capital gain or in-

that "the payment of a judgment against a corporate officer in these circumstances would ordinarily be deductible as a straight income loss." Commissioner v. Bauer, $193 \mathrm{~F} .2 \mathrm{~d}$ 734, 735 (2d Cir. 1952). However, since Bauer was also liable as a transferee and, as such, held entitled to only a capital loss deduction, "the accidental fact that Baucr was liable both as officer and transferee, did not give him the option of picking which liability he would satisfy, according to its tax consequences, when, as here, satisfaction of one liability discharged the other.... [T] ${ }^{2}$ he fact that he was personally liable for the judgment is superfluous." Ibid.

More recently, the Second Circuit followed Baner, treating the repayment as a capital loss, and reversed the Tax Court's holding, based on Szitlik, of an ordinary loss deduction. Milliken v. Commissioner, 5 CCH 1952 FED. TAX REP. I 9284 (2d Cir. 1952), reversing 15 T.C. 243 (1950). The court reiterated that the repayment "was related to, and therefore viewed practically was a reduction of, a previous capital gain or an increase of a previous capital loss" and "by definition [transferee] liability stems from the liquidation distribution which, under I.R.C. $\$ 115$ (c), is a capital transaction." Id. at p. 45, 646. See note 27 infra.

18. INT. Rev. Code $\S 23(\mathrm{e})$. A "net-operating loss," however, may be carricd back for one year and forward for five years. INT. REv. CoDE $\S 122$.

19. INT. REv. CODE $§ 117$ (d) (2). None of a corporate taxpayer's capital loss may be deducted from ordinary income. INT. REv. CODE § 117 (d) (1).

20. INr. REv. CODE $\S 117$ (c).

21. Long-term capital gains, in excess of capital losses, are, at the taxpaycr's option, either cut in half and taxed at regular rates or are taxed in full at 26 per cent. INT. Rev. CODE 117 (b) (c).

22. Cf. "[T] he loss ... grew out of and was at all times potentially a result from the distribution. ... [T] he transferee liability [was] incurred solely because of a corporato distribution of too great an amount ;... in effect, the petitioner is merely paying after much delay the tax which should have been paid by either the corporation or the stockholders currently as a result of the distribution." Disney, J., dissenting, in Stanley Switlik, 13 T.C. 121,127 (1949). 
creased a capital loss: one lightly taxed, and the other of limited deductibility. Under the Switlik rule, therefore, stockholder-managers of a liquidating corporation may find it rewarding to underestimate the corporation's tax obligations-the context in which transferee payments most frequently provolie later tax litigation ${ }^{23}$-and also to postpone settlement of non-tax liabilities. When the transferees do eventually meet their liability, the Suitlik rule rewards them with the more desirable ordinary loss deduction. Where ta: claims against the corporation create the transferee liability, the Code's sanctions against tax underpayment are unlikely to deter such stockholder maneuvers. The interest charges imposed by the Code for non-fraudulent underpayment will usually not approach the tax benefit of ordinary loss treatment."And the Government cannot easily prove actual fraud, subject to penalty rates or criminal prosecution, ${ }^{25}$ or even the "untoward motivations" which, the Switlik court intimated, might have resulted in disallowance of the ordinary

23. The transferee liability in all of the reported cases except Baucr arose from tax: claims against the corporation. For a collection of these cases, see $2 \mathrm{CCH} 1952$ FED. TAX REP. II 833.11-833.116. These litigants typically are controlling stoctholders of closely-held corporations. Ibid. See note 38 infra.

24. Interest on all underpayments is six per cent. Ixr. Rev. Cone $\$ 292$. If any part of a deficiency is due to negligence or intentional disregard of rules and regulations without intent to defraud, an additional five per cent of the deficiency is assessed. In:T. Res. CODE $\$ 293(a)$.

A six or eleven per cent added assessment will rarely offset the benefits of the transmutation from capital to ordinary loss. Assume the sole stochholder of a liquidating corporation has a constant net income of $\$ 10,000$ and no capital gains or losses other than a longterm gain of $\$ 3000$ on his liquidating dividend. Since only half of this gain is tasable if the taxpayer elects to pay at ordinary income rates, his net taxable income would be $\$ 11,500$. If a non-negligent tax deficiency of $\$ 1000$ plus six per cent interest were assessed against the corporation one year later and paid by the transferee, an ordinary deduction in the later year would reduce his taxable net income for that year to $\$ 8,940$. The two year total would be $\$ 20,440$. On the other hand, if the corporation had paid the proper tax prior to liquidation, the taxpayer's liquidating dividend gain would have been $\$ 2,000$ and the total two year taxable income would have been $\$ 21,000$. The taxpayer has thus received a $\$ 560$ deduction worth, in his tax bracket, approximately $\$ 140$. Reduced by the interest payment of $\$ 60$, there is still a net tax saving of $\$ 80$. If an additional five per cent were assessed for negligent underpayment the saving would be approximately $\$ 42$. And in either case, the taxpayer also receives the use of $\$ 1,000$ for one year. The difference between the two treatments would be magnified when the transferee chooses the option of paying a 26 per cent rate on capital gains. See INT. Rev. Cone $\$ 117$.

The Commissioner has not challenged the transferee's right to take an ordinary deduction for the payment of interest charges accrued since liquidation. See, e.g., Eastland v. Lnited States, 103 F. Supp. 182 (W.D. Tex. 1951).

25. A 50 per cent penalty is charged against deficiencies "due to fraud with intent to evade tax." INT. REv. Cone $\$ 293$ (b). The Code also provides for criminal penalties up to $\$ 10,000$ fine and five years' imprisonment for willfully attempting to evade a tas. I:IT. REv. CODE $\S 145(\mathrm{~b})$.

The necessity of proving a subjective intent to defraud, the wide area of reasonable differences of opinion, and the often subtle distinction between evasion and avoidance impuse a heavy burden on the Government. See Gordon, Income Tax Penaltics, 5 TAx L. REv. 131 (1950); Spencer, Proof of Income Ta.t Fraud, 2 TAx L. Rev. 451 (1947). 
loss deduction. ${ }^{26}$ Likewise, in non-tax transferee liability the accumulation of interest charges on contract obligations will rarely nullify the tax saving opportunities suggested by Switlik.

The Bauer court's stretched interpretation of the Code's capital loss provisions, ${ }^{27}$ on the other hand, seems unnecessarily hard on the taxpayer. True, a lesser liquidating dividend would have reduced the capital gain resulting from the distribution. But the court's justification of capital loss treatment in the repayment year, by reference back to the capital gains consequences in the earlier year, ${ }^{28}$ oversimplifies the matter. Transferee payments often involve

26. "We need only note that the Commissioner has not asserted, nor has the Tax Court found, any untoward motivation for the distributions in liquidations which should bring about a different result." Commissioner v. Switlik, 184 F.2d 299, 302 (3d Cir. 1950). CF. Clifton v. Allen, 101 F. Supp. 977, 998 (M.D. Ga. 1952) : "The dissolution and liquidation of the corporation was made in good faith with no apparent purposes of defeating tax lia* bility." But cf. the Bater case, in which an ordinary loss deduction was allowed by the Tax Court despite the fact that the corporation's liability was being litigated at the time of liquidation. See note 14 supra. On appeal, the Commissioner did not attempt to distinguish the Szeitlik case upon this ground, but instead made a frontal attack upon that precelent. Brief for Petitioner, p. 7, Commissioner v. Bauer, 193 F.2d 734 (2d Cir. 1952). In Milliken v. Commissioner, 5 CCH 1952 FEd. TAX REP. I 9284 (2d Cir. 1952), the Circuit which decided the Baner case rejected the transferee's contention that his lack of knowlcdge of the potential claim at the time of liquidation made the Bauer holding inapplicable. Id. at p. 45, 646. See note 32 infra.

Assuming that some "untoward motivation" were found, it is difficult to see what a court would do under the Szevitlik doctrine. After once holding the payment an ordinary loss, it could not well turn around and penalize a taxpayer by finding only a capital loss after all; the transaction would not be any more "sale or exchange" than before. The deduction might be denied altogether, although the payment would be no less a loss within the terms of the statute. Cf. Lilly v. Commissioner, 343 U.S. 90 (1952) (oculist allowed business deduction for rebates paid to doctors despite Commissioner's contention that public policy was being frustrated thereby).

27. The Code defines capital losses as those resulting "from sales or exchanges of capital assets." INT. REv. CODE $\$ 23(\mathrm{~g})$. However, the Second Circuit read $\S 23$ (g) to cover not only sales or exchanges, but also transactions "arising out of a 'sale or ex:change." "Commissioner v. Bauer, 193 F.2d 734, 735 (2d Cir. 1952). But "not every gain growing out of a transaction concerning capital assets is allowed the bencfits of the capital gains tax provision. Those are limited by definition to gains from the sale or exchange of capital assets." Dobson v. Commissioner, 321 U.S. 231, 232 (1944). Moreover, the Second Circuit on the one hand accepted the principle of the single year as the unit of taxation, for the purpose of treating the liquidating dividend and the transferee repayment as two taxable events in separate years. On the other hand, the court lumped both transactions into onc for holding the repayment a capital loss "arising out of" the liquidating dividend. It relied on Westover v. Smith, 173 F.2d 90 (9th Cir. 1949), and Commissioner v. Carter, 170 F.2d 911 (2d Cir. 1948), where stockholder=taxpayer had received contract rights of unascertainable value at the time of corporate liquidation. There taxpayers prevailed: the income subsequently received from the obligors under the contracts was held to be capital gains as an integral part of the liquidation. Thus these decisions merely implement $\S 115$ (c), trenting liquidation distributions as capital gain to recipients. But cf. Duveen Brothers, 17 'T.C. 124 (1951), discussed at note 39 infra.

28. Commissioner v. Bauer, 193 F.2d 734, 735 (2d Cir. 1952). See notes 27 supra, 32 infra. 
large amounts, ${ }^{29}$ and capital losses are of limited offset value. If offset in the year when liquidating dividends are received, sufficient capital gains from the liquidating distributon probably exist against which capital losses can be applied to reduce tax liability. ${ }^{30}$ A capital loss in the year of repayment, however, may be useless to the taxpayer; the repayment may well exceed his capital gains in the succeeding five years as well as the $\$ 6000$ of ordinary income against which it can be offset. ${ }^{31}$ Thus the Baucr reasoning, though viewing the transaction more realistically than Savitlik, may harshly penalize the innocent taxpayer. ${ }^{32}$

Orthodox application of the "claim of right" doctrine ${ }^{33}$ accounts for the inadequacy of the Switlik and Baucr results. The rule against reopening

29. In stockholder-transferee cases decided since 1941, the following amounts were paid by the principal stockholders (to the nearest $\$ 100$ ): Commissioner v. Milliken, $5 \mathrm{CCH}$ 1952 FED. TAX REP. II 9284 (2d Cir. 1952) (\$33,400); Commissioner v. Bauer, 193 F.2d 734 (2d Cir. 1952) (\$18,000); Clifton v. Allen, 101 F. Supp. 997 (1I.D. Ga. 1952) (\$6,000); Eastland v. United States, 103 F. Supp. 182 (W.D. Tex 1951) (\$12,000); Frederic M. Paist, 10 T.C.M. 967 (1951) (\$S,600); Roberta Pittman, 14 T.C. $449(1950)(\$ 2,600)$; Commissioner v. Switlik, 184 F.2d 299 (3d Cir. 1950) (\$22,500); Estate of Mrills, 4 T.C. 820 (1945) (\$5,700); Koppers Company, 3 T.C. 62 (1944) (\$200,000); Schramm v. United States, 36 F. Supp. 1021 (Ct. Cl. 1941) (\$4,900). But cf. J. C. Wynne, 47 B.T.A 731 (1942) (\$120 transferee assessment was deducted by taxpayer from his liquidating dividend and the Commission did not disallow it).

30. Of course, if the original liquidating dividend resulted in a capital loss to the transferee, an offset in the earlier year might still be wasted. But in all reported cases in which the treatment of transferee payments was in issue, the taxpayers realized a capital gain upon the original distribution. See cases collected in 2 CCH 1952 FEv. TAx REs. III \$33.11\$33.116.

31. See substantial amounts of transferee payments in cases at note 29 sugra.

32. The Bauer court, at least, considered the liquidation and the transferce payment as related transactions. Of course, the court, even if it wished, could not have allowed reopening since the issue was not before it and the statute of limitations had run on the earlier return. The court did, however, reiterate the "principle that a tax return fur a previous year may not be reopened to reflect a subsequent fact." Commissioner v. Bauer, 193 F.2d 734, 735 (2d Cir. 1952).

Since, in the Bauer case, the suit against the corporation was pending at the time of liquidstion, see note 14 supra, the stockholders might have protected themselves by leaving a reserve in the corporation. However, the Second Circuit has applied its decision in Baucr to cover a situation where a stockholder-transferee, at the time of liquidation, had no knowledge of the potential liability. Milliken v. Commissioner, 5 CCH 1952 FED. TAX REP. If 9284 (2d Cir. 1952). See note 47 infra.

33. The prohibition against deducting a present loss from related prior income has been applied to such situations as: relinquishment of royalties derived from land, title to which was in dispute, McDuffie v. United States, 19 F. Supp. 239 (C. Cl. 1937) ; repayment of judgment awards upon reversal of lower court decisions, Commissioner v. Alamitos Land Co., 112 F.2d 648 (9th Cir.), cert. desied, 311 U.S. 679 (1940), see North Ameriean Oil v. Burnet, 286 U.S. 417, 425 (1932), stpra note 7; return of income received in unlawful transactions, National City Bank v. Helvering, 98 F.2d 93 (2d Cir. 1938), cf. Rutsin v. United States, 343 U.S. 33 (1952) (money obtained through extortion tasable as income although legal obligation to repay), but cf. Commissioner v. Wilcox, 327 U.S. 404 (1946) (embezzled funds not taxable income-in view of Rutlin, of dubtful precedent 
an earlier return when income once received under a "claim of right" is later repaid makes for the expeditious final settlement of tax returns. ${ }^{34}$ Nevertheless, splitting what is essentially a single transaction into two taxable events may, depending on the taxpayer's later income bracket or changes in tax rates, arbitrarily confer a windfall or a wasted ordinary deduction. ${ }^{36}$ The peculiarities of stockholder-transferee payments magnify the doctrine's arbitrary workings. The Baller rule, granting only a capital loss of limited deductibility, increases the possibility of a wasted deduction. ${ }^{36}$ And since the original liquidating dividend is a capital transaction, the Switlik ordinary loss deduction results in an almost certain windfall. ${ }^{37}$ Corporate liquidation, moreover, where stockholders can control the mechanics and amount of a distribution to themselves, is singularly suited to profitable tax manipulation. . $^{\text {s }}$

value today) ; and repayment of monies received under a mistake of fact, United States v. Lewis, 340 U.S. 590 (1951) (recipient of bonus overpaid because of miscalculation legally obligated to return excess.).

For other claim of right cases, see 2 Mertens, LAw of Federsl Income TAXation $\S \S 12.103,12.104$ (1942); Comment, 58 Y Ale L. J. 955, 960 (1946); Note, 154 A.L.R. 1276 (1945).

34. "The principle underlying the 'claim of right' theory . . . finds support in its facilitation of the taxing statute and that is probably sufficient justification for its departurc from the emphasis on fixation of liability and the importance of contingency underlying the theory of accrual." 2 Mertens, Law of Federal InCOME TAXATion $\$ 12.103$ at 301 (1942). "Income taxes must be paid on income received (or accrued) during an annual accounting period. . . . The 'claim of right' test has long been used to give finality to that period." United States v. Lewis, 340 U.S. 590, 592 (1951). But see Comment, Taxing Unsettled Income: The "Claint of Right" Test, 58 YALE L. J. 955, 968 n.53 (1949) (questioning the supposition that allowing refunds upon repayment of unsettled income would be administratively burdensome).

35. Critics of the doctrine have emphasized the hardship, rather than the windfall possibility. See Henderson, Introduction To Income Taxation 237 (2d ed. 1949); Magill, Taxable Income 204 (Rev. ed. 1945) ; Montgomery, Accounting and the Conctht of Income in Lectures on Taxation 55 (1932): "[North American Oil v. Burnet] is taxation . . . with a vengeance. It seems highly inequitable that the money as to which litigation is still pending should be deemed to be taxable. It means that when paid back: later to the rightful owner, the temporary custodian may have paid a tax in a year when he was taxable and it is cold comfort for him to be told he can deduct the repayment as a loss when he has no taxable income." See further Magill, When 1s Incame Realized?, 46 Harv. L. Rev. 933 (1933) ; Comment, Taxing Unsettled Income: The "Claim of Right" Test, 58 Y ALE L. J. 955, $956 \mathrm{n} .9$ (1949): "Restitution may, of course, take place in a ycar of higher tax rates or larger gross income, permitting a deduction which would more that offset the original tax. But most types of unsettled income are unusual receipts which substantially increase total income of the year in which received." See also Justice Douglas' dissent in United States v. Lewis, 340 U.S. 590,592 (1951).

36. See discussion in text supra.

37. See note 24 supra.

38. Transferee tax liquidation usually involves stockholders of closely-held corporitions. See note 23 supra.

The use of corporate liquidations to convert ordinary income into capital gains has been a favorite target of commentators. See, e.g., the excellent discussion in Bittker is 
Since stockholder-transferee liability is the only significant repayment situation in which the original "claim of right" receipt is a capital transaction, ${ }^{39}$ it might well be excepted from the rule barring the reopening of prior returns. Of course, the "claim of right" doctrine might be generally modified, permitting adjustment of the earlier return wilkncver income received under a "claim of right" was later repaid. ${ }^{40}$ But to make such a change workable, the present statute of limitations on tax refunds would have to be extended ${ }^{11}$ -a proposal of dubious merits. ${ }^{42}$ Exception of stockholder-transferee payments from the general rule against reopening of prior returns could, however, operate within the present limitations period. Where a corporate tax deficiency created the transferee liability, the Commissioner would have to proceed against the corporation for pre-liquidation taxes before the three-year statute of limitations in turn barred transferees from claiming a refund. ${ }^{23}$ The former stockholders would have ample time to know of tax assessments

Redlich, Corporate Liquidation And The Income Tax, 5 TAx L. Rev. 437 (1950), of the use of a "collapsible corporation, one more of the perenially alluring contrivances for transmuting ordinary income into capital gain." In 1950, Congress denied the liquidating dividend capital gains provisions to stockholders of collapsible corporations. Inv. REv. CODE $\$ 117(\mathrm{~m})$.

39. Duveen Brothers, 17 T.C. 124 (1951), is the unique litigated exception in which a deduction has been allowed. There a corporate taxpayer sold a block of stock in another corporation which was redeemable at the issuer's option, agreeing to pay the difference between purchase and redemption prices if the stock was called. The taxpayer reported a long-term capital gain on the sale. In a subsequent year, the stock was redeemed and the taxpayer was obliged to fulfill its guaranty. The Tax Court, four judges discenting, distinguished Surtlik and restricted the taxpayer to a capital loss deduction. This type of situation, however is not likely to arise often. See $2 \mathrm{CCH} 1952$ FED. TAx REs. II 833.11-833.116; 3 id 9 865.37. Compare William F. Davis, 17 T.C. 549 (1951) (corporate officer, repaying corporation because of violation of $16(b)$ of the Securities Excluange Act. denied deduction although earlier capital gain was taxed) ; I.T. 4069, 1052 INT. RE: BrLr. No. 2 at 3 (1952), with Dobson v. Commissioner, 321 U.S. 231 (1944) (amounts reecvered by purchaser of stock from fraudulent seller treated as ordinary income even thugh taxpayer sustained loss on resale prior to recovery).

40. See note 41 infra.

41. Various proposals for modifying the annual accounting principle have urged extension of the statute of limitations on refund claims. See Magill, II"hen Is Incomse Realized?, 46 HARv. L. REv. 933, 953 (1933) (no limit whatever); Comment, 58 Yale L. J. 955, 967 (1949) ("such as . . ten years of the original return").

In United States v. Lewis, 370 U.S. 590, 592 n.1 (1951), the Court stated: "While the suggestion [to reopen respondent's return for equitable reasons] might work to the advantage of this taxpayer, it could not be adopted as a general solution bzeause, in many cases, the three-year statute of limitations would preclude recovery."

42. See note 34 supra.

43. A refund may be claimed within three years from the time the return is filed by the taxpayer or within two years from the time the tax is paid. INT. Rav. Curs §322(b) (1). The period of limitations for filing a deficiency assessment against the corporate taspayer is three years from the due date of the return. INT. REv. CoDE $\$ 275(a)$. Moreover, the Code specifically provides that a corporation contemplating dissolution may have its assessment limitations period shortened to eighteen months from the time of request. I::r. Rs:. 
for the years prior to the liquidating year.44 And liquidators might easily protect transferees from a "midnight" assessment against the corporation for the year of liquidation by taking advantage of the shortened tax limitations period allowed dissolving corporations. ${ }^{45}$ Contract and most tort liability is easily ascertainable. And although potential tort claimants might be unknown, the bar dates on tort litigation and on suits against dissolved corporations would generally compel initiating such proceedings before the tax statute of limitations barred the stockholders from seeking refunds. ${ }^{40}$

Even when, at the end of the tax refund limitations period, claims against the liquidated corporation were pending but not yet finally settled, adjustment of the transferees' returns could be easily ensured. The dissolving corporation might retain a reserve to meet contingent liabilities, scaling down the size of the liquidating dividends accordingly. ${ }^{47}$ Or, at any time before the refund

CODE $\S 275(\mathrm{~b})$. The assessment period is extended to five years where an erroneous omission from gross income exceeds 25 per cent of the reported gross income, INT. Rev. CODE $\S 275(c)$, and is unlimited where no return or a false or fraudulent return has been filed. INT. Rev. CODE § 276(a).

44. For example, a corporation dissolves and pays a liquidating dividend in 1950. An ordinary tax deficiency can not be assessed against the corporation later than March 15, 1954. (The period runs from the last day prescribed by law for filing the return. See INT. REv. CODE $\$ 275(f))$. A stockholder required to make good part of this deficiency may also claim a refund on his 1950 return, in which the liquidating dividend was reported, until March 15, 1954. See INT. Rev. Code § 322 (b) (4).

Transferee liability does not attach to assets transferred before the debt is incurrcd. Harwood v. Eaton, 68 F.2d 12 (2d Cir. 1933). Therefore, the stockholder will be able to reopen his return even where the liquidation takes place over a number of years and the corporation's tax liability is incurred for a year subsequent to the receipt of a liquidating dividend.

45. If the Commissioner waited until almost the end of the limitations period before assessing a deficiency against the corporation, the transferees might, of course, have difficulty in claiming a refund before being barred by the statute. The Code provides, however, for a shortening of the period of assessment for dissolving corporations to eighteen months from the time of request. INT. REv. CODE $\S 275(b)$; U.S. Treas. Reg. 111, $\S$ 29.275-1(a) (1943).

46. Examples of the limitations period on personal injury actions are: DEL. REv. Cove c. $146 \S 10$ (1935) (one year) ; Irz. Rev. Stat. c. $83 \$ 15$ (1951) (two years); N.Y. Civ. Prac. Act $\$ 49$ (three years for negligence actions); PA. StAT. ANN. tit. $12 \S 34$ (1931) (two years).

At common law, dissolved corporations lacked capacity either to sue or be sued, and pending actions abated upon dissolution. 16 Fletcher, CYCLOpedia of Private CoRporaTIONS $\S \S 8142,8147$ (Rev. ed. 1942). Statutes have largely removed this disability but they place a time limitation, frequently three years from dissolution, on actions brought against the corporation, $16 \mathrm{id}$. $\$ 8143$. For a discussion of the use of corporate dissolution to escape liability through shorter limitation period, see Hornstein, Voluntary Dissolution-A New" Development In Intracorporate Abuse, 51 YALE L. J. 64 (1941). See also Marcus, Suability of Dissolved Corporations-A Study in Interstate And Federal-State Relationships, 58 HARv. L. REv. 675 (1945) (emphasizing criminal liability).

47. Retaining a reserve would also ensure that no stockholder would pay more than his ratable share in meeting the corporate liability. The right to pro rata contribution 
statute of limitation had run, the transferees could deposit with a liquidation trustee moneys to cover the contingent liability, and at that time reopen the liquidating dividend tax return. ${ }^{48}$ If the claimant eventually prevailed, collection of his judgment would be expedited; he would not have to seek satisfaction from individual transferees. ${ }^{49}$ And in either case, any excess remaining after settlement of the claim could then be distributed and treated as a final liquidating dividend. ${ }^{50}$

To encourage early settlement of claims and preclude windfalls, permitting the reopening of prior returns should be accompanied by denial of deductions in the repayment year. ${ }^{51}$ Thus taxpayers would be encouraged to settle outstanding liabilities expeditiously, since only repayments within the limitations period would qualify them for reopening their returns. And unless deductions in the later year is barred, taxpayers would be free to choose between an equalizing adjustment and a deduction -an invitation to judicious delay in settlement until a strategic deduction year. ${ }^{\text {.2 }}$ In sum, courts should return to their earlier practice ${ }^{53}$ which recognized the realities of stockholdertransferee payments: reductions of the liquidating dividend.

from other transferees, Phillips-Jones Corp. v. Parmley, 302 U.S. 233 (1937), may well prove illusory. The very fact that one stockholder has been required to pay more than his proportionate share indicates possible difficulty in collecting from the others. But requiring a liquidating corporation to keep a reserve, see Note, 38 A.B.A.J. 245 (1952), is not an adequate solution to the problem of avoiding Baucr treatment of the transferee payment. Iiquidators should not be deprived of the immediate use of their funds on the mere chance that someone, unknown at the time of liquidation, has an outstanding claim against the corporation for an undetermined amount. See note 32 sipra.

48. Where a tax deficiency is assessed, the transferees, even if intending to contest, might well pay the claim immediately. If then they succeed in reducing the liability, the amount refunded will have earned six per cent. INT. Rev. Cons \$ 3771 .

49. Besides the numerous procedural difficulties which face a creditor trying to collect from transferees, see 15A Fletcher, Cyclopenda of Parvate Corfonatio:s $\$ \$ 7580(1)$ 7593 (Rev. ed. 1938), other problems may also be encountered. For example, the corporate assets may have been dissipated in many hands and transferees may be difficult to loeate; a creditor also runs the risk of the individual stockholder's insolvency.

50. The amount received would be similar to a final installment of a series of liquidation distributions. With the 1941 repeal of the tax distinction between complete and partial liquidation, this final payment would receive standard capital gains treatment. Inr. REv. CODE $\$ 115$ (c).

51. This was the prior practice. Benjamin Paschal O'Neal, is B.T.A. 1036 (1930).

But for the difficult administrative supervision, susequent deduction might be allowed whenever the transferee did not learn of his potential liability until the refund statute of limitations ran out. This, however, would be unusual. The Bater decision is the only reported transferee repayment deduction case not involving corporate tax liability, and even there the suit was pending at the time of liquidation. See cases collected in $2 \mathrm{CCH}$ 1952 Fed. TAX REP. If $833.11-\$ 33.116$.

52. A loss deduction must be taken in the year in which the loss is sustained. Inr. REv. Code $\$ 23(\mathrm{e})$. But transferees might well wait until a favorable tax year and then compromise the claim.

53. See note 3 supra. 